\title{
BASIC BRANDING CONCEPTS: BRAND IDENTITY, BRAND IMAGE
}

\section{AND BRAND EQUITY}

\section{RAMYA JAIN}

Assistant Professor Ramanujan College University of Delhi, India

\section{ABSTRACT}

Branding is not a modern concept, but it existed prior to the 20th century. The oldest generic brand in continuous use in India since the Vedic period is Chyawanprash. The importance of branding cannot be neglected in today's competitive world. Brand Identity, brand image and brand equity are important aspects of branding. The outward expression of the brand, including its name, logo, tone, tagline, symbols and visual appearance is a brand's identity. It should be meaningful, distinct and flexible. A brand image is how the consumers perceive the brand. The brand image is not created, but is automatically formed. A strong brand image is a powerful asset and makes people confident that the organization is dependable. Brand equity is the value that the customer attaches to a particular brand. Brand equity can provide a platform for growth by brand extensions. The paper attempts to explain the above mentioned concepts of branding

KEYWORDS: Brand Identity, Brand Image, Brand Equity, Symbols \& Attributes

Received: May 16, 2017; Accepted: Jun 08, 2017; Published: Jun 27, 2017; Paper Id.: IJSMMRDAUG20171

\section{INTRODUCTION}

According to the American Marketing Association, "brand is a name, term, sign, symbol, or design, or a combination of these, intended to identify the goods or services of one seller or group of sellers and to differentiate them from competitors". Some examples of well known brands are Mc Donald's', Mercedes-Benz, Sony, Coca Cola, Kingfisher, Apple, Adidas etc. Branding is the act of imprinting or engraving a brand name or symbol onto a product to provide a distinct individuality to the product. The importance of branding cannot be neglected in today's competitive world. Brand Identity, brand image and brand equity are important aspects of branding. The paper summarizes these concepts, tries to explain their importance for both the firm and the consumers and how a firm can efficiently build them.

\section{RESEARCH METHODOLOGY}

Secondary sources have been used to carry out the present study. Various refereed books and research articles have been referred.

\section{BRAND IDENTITY}

The outward expression of the brand, including its name, logo, tone, tagline, symbols and visual appearance is a brand's identity. It is the most fundamental means of consumer recognition and symbolizes the brand's differentiation from competitors. A company's brand identity is how that business wants to be perceived by consumers. 


\section{Sources of Brand Identity}

- Symbols: Symbols help customers memorize organization's products and services as they are visual images. These can include logos, people, geometric shapes, cartoon images, anything. For instance, Marlboro has its famous cowboy, Pillsbury has its Poppin' Fresh doughboy, Duracell has its bunny rabbit, Mc Donald has Ronald, Fed Ex has an arrow, and Nike's swoosh.

- Logos: A logo is a unique graphic or symbol that represents a company, product, service, or other entity. Adidas's "Three Stripes" is a famous brand identified by it's corporate logo. The elements of a logo are:

- Logotype - It can be a simple or expanded name. Examples of logotypes including only the name are Kellogg's, Hyatt, etc.

- Icon - It is a name or visual symbol that communicates a market position. For example-LIC 'hands', UTI 'kalash'.

- Slogan - It is best way of conveying company's message to the consumers. For instance- Nike's slogan “Just Do It". Apple's tagline is "Think different".

- Signature tune: It is a unique tone that reminds customers of specific company's brand. For example - Britannia "ting-ting-ta-ding", Nokia, Windows also use a signature tune.

\section{Importance of Brand Identity}

Today we live in a culture that is rich in knowledge yet deprived of time. Because of this, it is often the visual identity of a brand that catches the eyes of consumers. In many cases, people tend to form their opinions and perceptions about a brand before they even know who it is and what it is about. This is why visual presence is essential in order to differentiate brand effectively amongst the competition, and build trust with consumers.

\section{Elements Important to Brand Identity}

- Meaning: Great brands stand for something. A brand's identity must express the organization's unique mission, history, culture, values, and personality.

- Differentiation: Brands are always competing with each other within their business category that wants the attention of consumers. Because of all of this competition, it is not enough to just be different. Brands need to demonstrate and communicate their difference, making it easy for customers to understand that difference.

- Durability \& Flexibility: Brands need to commit to a central idea over time in order to transcend change and remain recognizable. An effective brand identity positions a company for change and growth in the future. It supports an evolving marketing strategy.

\section{BRAND IMAGE}

A brand image is how the consumers perceive the brand. It is a set of beliefs held about a specific brand. It signifies what the brand presently stands for. Consumers develop various associations with the brand. Based on these associations, they form brand image. It is a unique bundle of associations within the minds of the target audience. Ex: Volvo is associated with safety, Toyota is associated with reliability.

Keller's (1993) defines brand image as "perceptions about a brand as reflected by the brand associations held in consumer memory". According to him, brand image consists of various associations in consumers' mind namely attributes, benefits and attitudes. 
- Attributes: Brand attributes are the functional and mental connections with the brand that the customers have. Attributes are "descriptive features that characterized a product or service - what a consumer thought the product or service is or has and what is involved with its purchase or consumption" (Keller, 1993). He classified attributes into product-related attributes and non product-related attributes. Product-related attributes are the attributes which are basis for the proper functioning of the products and services. Hence, they relate to a product's physical composition or a service's requirements. They determine the nature and level of product performance. Non product-related attributes (i.e. price, packaging or product appearance information, user imagery i.e. what kind of person uses the product or service and usage imagery i.e. in what situations the product or service is used) are the external attributes of product and services which are purchase and consumption related. They may affect the purchase or consumption processes but do not directly affect the product performance.

- Benefits: Benefits are the rationale for the purchase decision. Keller (1993) classified benefits into functional, experiential and symbolic benefits. Functional benefits are related to the intrinsic advantages derived from the consumption of product or services usually because of the product related attributes (example: hunger satisfaction from food). These benefits often are linked to the basic motivations, such as physiological and safety needs. Experiential benefits answer the question; what it feels like after using the product or service (example: happy, contented, excited etc.). These benefits satisfy experiential needs such as sensory pleasure. Symbolic benefits are the extrinsic benefits derived from product or service use and are related to non-product attributes (example: satisfaction of social needs or self-esteem needs).

- Attitudes: Attitudes are consumers overall assessment of a brand. Brand attitudes are important because they often form the basis for actions and behavior that consumers take with the brand (e.g., brand choice). Consumers' brand attitudes generally depend on specific considerations concerning the attributes and benefits of the brand.

Brand image is not created, but is automatically formed. It is a function of expectations and experiences. When customer's experience is better than their expectations, they tend to develop a positive brand image. When customer's experience falls short of their expectations, they tend to develop negative brand image.

Example: Brand image of Harley Davidson: Harley Davidson is associated with powerful, distinctive cruiser motorbikes. Also, it is associated with freedom on the road with a little of the rebel thrown in. People buy Harley Davidson motorbikes and associated products such as clothes, because they want to associate with powerful cruiser motorbikes and the freedom of the road.

\section{Importance of Brand Image}

Brand associations are important to marketers and to consumers. Marketers use brand associations to differentiate, position, and extend brands, to create positive attitudes and feelings toward brands, and to suggest attributes or benefits of purchasing or using a specific brand. Consumers use brand associations to help process, organize, and retrieve information in memory and to aid them in making purchase decisions (Aaker, 1991). Brand image helps marketers to identify the strengths and weaknesses of their brand as well as consumers' perceptions toward their product or services. A strong brand image is a powerful asset and makes people confident that the organization is dependable.

Example: The Apple brand stands for innovative products, the application of ground breaking technology, high quality products that are well made and superior to their rivals. Customers buy Apple products because they want to be associated with high quality and innovative technology. 


\section{BRAND EQUITY}

In general terms, brand equity is the value that customer attaches to a particular brand. It refers to the difference in the behavior of consumers towards a well known brand and a generic brand. If a consumer behaves more favorably to a branded product as compared to a generic product, then a brand has positive brand equity. If consumer reacts less favorably to a brand as compared to generic product, then a brand has negative brand equity. Brand equity represents the added value endowed to a product or a service as a result of past investments in the marketing for the brand. The additional money that consumers are willing to spend to buy Coca Cola rather than the store brand of soda is an example of brand equity.

American Marketing Association defined brand equity from a consumer's view point - "from a consumer perspective, brand equity is based on consumer attitudes about positive brand attributes and favorable consequences of brand use."

Aaker (1991) defined brand equity as "a set of assets and liabilities linked to a brand, its name and symbol, that add to or subtracts from the value provided by a product or service to a firm and/or to that firm's customers". The intangible assets of brands create the basis of brand equity. According to Aaker's Brand Equity Model (Five Assets Model), brand equity consists of five different asset dimensions. These assets include brand loyalty, brand awareness, perceived quality, brand associations, and other proprietary assets such as patents, trademarks and channel relationships. If managed well, these assets add value to the product or service and create additional customer satisfaction, which, in turn, provide a number of benefits to the firm. (Aaker, 1991)

- Brand loyalty: The brand loyalty of the customer base is often the core of a brand's equity. It refers to the degree to which customers are loyal to a brand. It reflects how likely a customer will be ready to switch to another brand, especially when that brand makes a change, either in price or in product features. As brand loyalty increases, the vulnerability of the customer base to competitive action is reduced. Brand loyalty, on a continuum ranges from the habitual buyer to the satisfied buyer to those who are truly committed. Brand loyalty results in reduction in the marketing costs, trade leverage, stability in revenue, ease in attracting new customers and lowers brand switching which gives company time to respond to the competitive threats. Positive word-of-mouth is likely to be very high.

- Brand awareness: It focuses on the degree to which a brand is known among the public which can be ascertained through brand recognition and brand recall. It is the ability of a potential buyer to recognize or recall that a brand is a member of a certain product category. Brand recognition requires confirmation of a prior exposure to the brand by the consumer, when given the brand as a cue. Brand recall is next higher level of brand awareness where consumers can correctly retrieve the brand from memory when given any cue related to such product category. Next higher levels of brand awareness are top-of-the-mind (first mentioned brand), brand dominance (the only brand recalled), brand knowledge (when consumers know what the brand stands for) and brand opinion (when consumers have an opinion about the brand). Brand awareness provides the anchor to which other associations can be linked. Recognition provides the brand with a sense of familiarity and people like the familiar. When consumer doesn't want to engage in attribute evaluation, familiarity may be enough. Brand awareness can be a signal of substance. The first step in the buying process is to select a group of brands to consider. Brand awareness is crucial to selecting the brand as a part of evoked set.

- Perceived Quality: Perceived quality can be defined as the customer's perception of the overall quality or superiority of a product or service relative to alternatives. The quality offered by the brand provides a reason to 
buy and it can be used as a strong positioning basis. It allows for charging premium prices as price is taken as a quality indicator. Channel members are motivated to carry brands that are well regarded. Also, the perceived quality can be exploited by introducing brand extensions, using the brand name to enter new product categories.

- Brand associations: A brand association is any mental linkage to the brand. There are different types of brand associations which can be classified into: 1) attributes, 2) benefits, and 3) attitudes. Attributes are "descriptive features that characterized a product or service - what a consumer thought the product or service is or has and what is involved with its purchase or consumption" (Keller, 1993). He classified attributes into product-related attributes and non product-related attributes. Benefits are the personal value and meaning that consumers attach to the product or service. Benefits can be further distinguished into three categories: functional benefits, experiential benefits, and symbolic benefits. Brand attitudes are defined in terms of consumers' overall evaluations of a brand. Consumers believe the brand has attributes and benefits that satisfy their needs and wants, so that a positive overall brand attitude is formed. Brand associations increase both the likelihood that information will be accessible and the ease with which it can be recalled, contributes to brand differentiation, gives a reason to buy and thus, facilitates buying process, develops positive attitudes and feelings and finally provide a basis for brand extensions.

- Other proprietary assets: Patents, intellectual property rights, relations with trade partners are some of the examples of proprietary assets. Brands which accumulate more proprietary assets tend to have greater competitive advantage relative to its competitors.

\section{Importance of Brand Equity}

The five asset dimensions (brand loyalty, brand awareness, perceived quality, brand associations and other proprietary brand assets) that underlie brand equity are creating brand equity. The five assets model implicates that brand equity provides value to the customer, as well as to the firm. The resulting customer value becomes a basis for providing value to the firm.

Brand equity provides value to the customer in at least three ways:

- Brand equity assets can help a customer to interpret, process, store and retrieve a huge quantity of information about products and brands.

- The assets can also affect the customer's confidence in the purchase decision, a customer will usually be more comfortable with the brand that was last used, is considered to have high quality, or is familiar.

- The brand equity assets, particularly perceived quality and brand associations, provide the customer with value is by increasing the customer's satisfaction when the individual uses the product.

- Brand equity provides value to the firm in at least six ways:

- Brand equity can enhance the efficiency and effectiveness of marketing programs. A promotion, for example, that provides an incentive to try a new flavor or new use will be more effective if the brand is familiar and is perceived to be of higher quality.

- Brand awareness, perceived quality, and brand associations can strengthen brand loyalty by increasing customer satisfaction and providing reasons to buy the product.

- Brand equity will usually provide higher margins for products by permitting premium pricing and reducing reliance on promotions. 
- Brand equity can provide a platform for growth by brand extensions.

- Brand equity can provide leverage in the distribution channel because channel members have less uncertainty dealing with a proven brand name that has already achieved recognition and has established strong associations.

- Brand equity assets provide a firm with a significant competitive advantage; a barrier that may prevent customers from switching to a competitor.

Strong brand equity of long standing may also result in that brand being used as the name of an entire category. Thus people say, "Let me get you a Xerox of that" even when the copier used is of another brand. In this situation the brand equity of Xerox copiers is clearly evident

\section{Leveraging Brand Equity}

There are three ways to leverage brand equity: firstly building it, secondly borrowing it, or thirdly buying it.

\section{Building Brand Equity}

Keller (2009) developed the brand resonance pyramid model in order to build strong brand equity. Keller's Brand Equity Model is also known as the Customer-Based Brand Equity (CBBE) Model:

- Brand Identity (Who is the brand?): The first step is to create "brand salience," or awareness - in other words, company needs to make sure that the brand stands out and that customers recognize it and are aware of it. It is concerned with; how often customer recognizes or recalls a brand and what cues are necessary to remind consumers about the brand. The basic idea is to create deep and broadened brand awareness i.e. how easily a brand is recalled and to what range of consumption situations a brand is recalled.

- Brand Meaning (What the brand means?): Next step is to identify and communicate what the brand means, and what it stands for. The two building blocks in this step are performance and imagery. Performance defines how well the product meets customers' basic needs and wants. According to the model, performance consists of five categories: product characteristics and features; product reliability, durability, and serviceability; service effectiveness, efficiency, and empathy; style and design; and price. Imagery refers to how well the brand meets customers' needs on a social and psychological level. Imagery has four categories: user profiles i.e. demographic profiles like age, gender, income etc. of the users of brand; usage imagery i.e. where or when can the brand be used; personality and values: people tend to purchase those brands that they feel match their personality; history, hierarchy and experiences: brand associations with history, hierarchy and experiences help build brand image. Brand meaning should be such that it results into a strong, favorable and unique brand association with the customers which in turn will help in eliciting responses from customers.

- Brand Response (How customers behave?): It focuses on how the customers respond to the marketing activities of brand and what they perceive brand as. The two building blocks are judgments and feelings. Customers constantly make judgments (rational response) about brand on the basis of: quality; credibility in terms of trustworthiness, and likability; consideration in terms of how relevant product is to their unique needs; superiority i.e. customers assess how superior brand is relative to its competitors' brands. According to the model, there are six positive brand feelings (emotional response) that can be evoked in customers: warmth, fun, excitement, security, social approval, and self-respect. Company should try to derive favorable brand responses from customers as it helps in developing strong customer relationships. 
- Brand Resonance (What is the relationship between customer and brand?): Brand resonance is achieved when customers feel a deep, psychological bond with the brand. Keller breaks resonance down into four categories: behavioral loyalty, this includes regular, repeat purchases; attitudinal attachment, when customers love brand or product, and they see it as a special purchase; sense of community, when customers feel a sense of community with people associated with the brand; active engagement, when customers are actively engaged with brand, even when they are not purchasing it or consuming it which includes joining a club related to the brand; participating in online chats etc.

- The strongest brands excel in all the brand- building blocks and they are properly synchronized with the needs and wants of customers.

\section{Borrowing Brand Equity}

Firms can borrow on the brand equity in their brand names by extending existing brand names to other products. The main purpose of using the same brand name is to take advantage of the value and power that the brand commands, rather than building a completely new brand, which would entail a huge expenditure, and would take time. Two types of extensions can be distinguished: a line and a category extension (also called brand extension).

- Line Extension: A line extension occurs when a company introduces additional items in the same product category under the same brand name. It involves products which are almost similar in many attributes but are different in terms of size, color, flavor or ingredient, or have a different form or a different application. Example: Bata expanded its footwear line to include regular shoes, sports shoes, sandals etc. Other example is Maggi noodles's extension from masala noodles to wheat noodles, multi-grain noodles, oats noodles etc.

- Brand Extension: Brand extension is the use of an established brand name in new product categories. The category to which the brand is being extended can be related or unrelated to the existing product categories in terms of product attributes, benefits, values, lifestyle etc. Example: Nestle' has leveraged the strength of its Maggi brand to launch several new lines: Maggi noodles, Maggi tomato ketchup, Maggi soups etc.

\section{Buying Brand Equity}

Company can also enhance brand equity by buying it through acquisition, licensing and co-branding.

- Acquisition: Acquisition of a firm, its brands and products is obviously one way of leveraging brand equity. Example: Google acquired Android, Youtube etc.

- Licensing: Organizations can get license from well established brand names to market their products. License can be for names, symbols, logos previously created by other manufacturers, names of well known celebrities, characters from popular movies and books. The licensee pays royalty or license fee for using established brand name and leverages their product using brand equity of established name. Example: Apparels and accessories sellers pay large royalties to adorn their products with the names of well-known fashion innovators like Calvin Klein, Tommy Hilfiger, Gucci etc.

- Co-branding: Co-branding occurs when two established brand names of different companies are used on the same product. Example: Citi Bank and Jet Airways joined forces to create Jet Citi Travel Card. 


\section{CONCLUSIONS}

It is often the visual identity of a brand that catches the eyes of consumers, so it is important to focus on developing a unique and meaning brand identity in order to differentiate brand effectively amongst the competition, and build trust with consumers. Consumers develop various associations with the brand. Marketers use these brand associations to differentiate, position, and extend brands and to create positive attitudes and feelings toward brands. Brand equity will usually provide higher margins for products by permitting premium pricing and reducing reliance on promotions. Brand equity assets provide a firm with a significant competitive advantage. Thus, a brand manager should put in a lot of efforts to build brand equity by developing a meaningful brand identity and monitoring brand image.

\section{REFERENCES}

1. Aaker, D.A. (1991), “Managing Brand Equity: Capitalizing on the Value of a Brand Name”, Free Press, New York.

2. Aaker, D.A. (1996), “Building Strong Brands”, Free Press, New York.

3. Kapferer, J.N. (2004), "The New Strategic Brand Management: Creating and Sustaining Brand Equity Long Term”, Kogan Page Publishers.

4. Keller, K.L. (1993), “Conceptualizing, Measuring, and Managing Customer-Based Brand Equity”, Journal of Marketing, Vol. 57, No. 1, 1-22.

5. Keller, K.L. (2009), “Building strong brands in a modern marketing communications environment”, Journal of Marketing Communications Vol. 15, Nos. 2 -3, 139-155.

6. Keller, K.L. (2013), "Strategic Brand Management: Building, Measuring and Managing Brand Equity", $4^{\text {th }}$ Edition, Pearson Education Limited.

7. Kotler, P. and Keller, K.L. (2006), “Marketing Management”, $12^{\text {th }}$ Edition, Prentice Hall of India, New Delhi.

8. Kotler, P., Keller, K.L., Koshy, A. and Jha, M. (2010), "Principles of Marketing: A South Asian Perspective”, Pearson Education, India.

9. American Marketing Association: https://www.ama.org/resources/pages/dictionary.aspx?dLetter=B Retrieved June 2, 2017 from https://www.ama.org 